\title{
Work related distal airway obstruction in an agricultural population
}

A Vergnenegre, X D'arco, B Melloni, M T Antonini, C Courat, M Dupont-Cuisinier, F Bonnaud

\begin{abstract}
Objective-To assess the prevalence of distal airway obstruction and its risk factors in agricultural areas.

Methods-A cross sectional study of respiratory symptoms and lung function was performed among French farmers and their spouses (1122 subjects) who came for preventive medicine examinations. They answered a respiratory questionnaire and performed pulmonary function tests on a portable spirometer. Diagnoses of chronic bronchitis were made on the basis of reported chronic respiratory symptoms. Airway obstruction was determined from predicted values. Odds ratio (OR) and linear regression coefficients were calculated after stratification by smoking and history of cardiac and other respiratory diseases.
\end{abstract}

Results-Of respiratory symptoms prevalence of chronic cough was $8.47 \%$, and chronic bronchitis $\mathbf{7 \cdot 6 6 \%}$. Prevalence of distal airway obstruction was $11.4 \%$, and overall airflow obstruction $3 \cdot 2 \%$. Smokers were $20 \cdot 2 \%$ men, and $5 \cdot 7 \%$ women. Linear regressions showed high association between pack-years in smokers or exsmokers and forced expiratory volume in one second/forced vital capacity (FEV,/VC) and forced expiratory flow between $25 \%$ and $75 \%$ of vital capacity $\left(\mathrm{FEF}_{25-75}\right)$. In non-smokers without any history of cardiac or respiratory diseases, age and the size of farms had the highest correlations with these variables. $O R$ for distal airway obstruction was $2 \cdot 1$ in subjects $>50$ years old $v$ the younger ones and 3.02 in the smaller farms $v$ the larger ones.

Conclusion-After stratification by smoking and history of cardiac and respiratory diseases, distal airway obstruction is present in agricultural areas. The age, and the size of farm are the highest respiratory risk factors in non-smokers.

(Occup Environ Med 1995;52:581-586)

Keywords: airway obstruction; chronic bronchitis; agriculture

It is now well recognised that agricultural workers have an increased risk of respiratory diseases. ${ }^{1}$ Most of the reported studies have dealt with parenchymatous diseases such as farmers' lung, although more recently, obstructive airway diseases have been described in agricultural populations. ${ }^{2-6}$ As these conditions are the end result of a series of lung cell interactions involving inflammation and responses of the immune system, long term exposure may transform the acute condition into chronic bronchitis. ${ }^{7}$ For example, grain farmers and silo workers have been reported to have a high risk of development of respiratory symptoms. ${ }^{89}$ In fact, agricultural workers are exposed to a wide variety of toxic materials including dusts, gases, microbial products, toxins, and numerous chemical compounds (pesticides and fertilisers). ${ }^{1}$ There is considerable variation in the reported prevalence of chronic bronchitis depending on the population studied and the nature of the agricultural activity. ${ }^{2-610-13}$ Although the prevalence of chronic bronchitis in the general population has been the subject of numerous studies, little has been reported on obstructive diseases in agricultural populations exposed to a wide range of respiratory hazards. ${ }^{1}$ Although the prevalence of smoking is lower than in the general population, ${ }^{14}$ rates of chronic bronchitis are higher for several groups of agricultural workers than for controls in non-rural areas. ${ }^{61516}$

Injuries to peripheral airways may be induced by inhalation of small particles or endotoxins $^{17}$ well before the appearance of respiratory symptoms. ${ }^{18}$ Peak expiratory flow rates (PEFRs) have been measured in grain elevator workers, ${ }^{19}$ and forced vital capacity (VC) and forced expiratory volume in one second $\left(F_{E V}\right)$ have been determined in workers in the grain industry. ${ }^{3819}$ Do Pico et al found an adverse dose related acute respiratory effect. ${ }^{8}$ Although overall airflow obstruction is readily diagnosed from the results of lung function tests $\left(\mathrm{FEV}_{1}\right.$ or $\left.\mathrm{FEV}_{1} / \mathrm{VC}\right)$ with high correlations with symptoms, ${ }^{3}$ distal airway obstruction is less easily quantified. It can, however, be assessed from the forced expiratory flow between $25 \%$ and $75 \%$ of vital capacity $\left(\mathrm{FEF}_{25-75}\right)$, in the presence of a reduction in other instantaneous flow variables. ${ }^{2021}$

This study was designed to estimate the prevalence of distal airway obstruction and to identify risk factors for obstructive diseases, after stratification by confounding factors such as smoking habits and history of non-obstructive respiratory diseases.

\section{Methods}

STUDY POPULATION

Every five years, all people aged between 16 and 65 years and their families, either living in 
agricultural areas or contributors to the "Mutualité Sociale Agricole" (MSA) are eligible for a free medical examination after receiving written notification from the relevant hospital department. Salaried employees undergo an obligatory annual medical examination. Farmers, employees, and their spouses were included in the study if they were engaged in mixed farming, livestock breeding, horticulture, or fruit growing. Workers in banks, dairy industries, sawmills, and forestry were systematically excluded.

\section{QUESTIONNAIRE}

The questionnaire was designed with the British Medical Research Council guide lines, and the French version was drawn up by the World Health Organisation. ${ }^{22}$ We added three questions: one about agricultural activity, one about the size of farm, and the last about working conditions (average time spent a week in agricultural activities, but it was not possible to assess average exposures for a working day from the questionnaire). The questionnaire was given before the lung function examination.

Chronic bronchitis was defined as cough and expectoration for three months a year for two consecutive years according to the criteria of the American Thoracic Society (1960). Atopy was defined from a history of infantile eczema, hay fever, asthma, or rhinitis. Smoking was classified into non-smokers, ex-smokers (abstinence for previous three months), and current smokers. The amount smoked annually in pack-years was recorded for the two smoker groups. Cardiac and respiratory history was defined as history of cardiac disease, pulmonary surgery, pleurisy, pneumonia or tuberculosis, and restrictive respiratory diseases.

\section{LUNG FUNCTION TESTS}

Lung function was measured with portable spirometers (flowmate Hellige, Jaeger France). Three measurements were taken for all subjects by operators experienced with this instrument. The VC, $\mathrm{FEV}_{1}$, and $\mathrm{FEF}_{25-75}$ were recorded. The best of the three curves was selected. Curves with poor reproducibility or of bad quality were rejected. Values were expressed as a percentage of the normal values of the European Coal and Steel Community (ECSC) values, which are calculated according to the age, sex, and height of the person. ${ }^{23}$

The lower limit for distal airway obstruction in people with a normal FEV, was a normal value of $\mathrm{FEF}_{25-75}$ less $1.74 \mathrm{1} / \mathrm{s}$ in men and less $1.39 \mathrm{l} / \mathrm{s}$ in women $(1.64 \mathrm{SD}){ }^{23}$ Distal airway obstruction was considered to be present if values were under these thresholds. The lower limit for overall airflow obstruction was the normal value of $\mathrm{FEV}_{1} / \mathrm{VC}$ less $11.75 \%$ in men, and less $10.68 \%$ in women (1.64 SD). ${ }^{23}$ Overall airflow obstruction was considered to be present if values were under these thresholds. A restrictive ventilatory impairment was defined as normal $\mathrm{FEV}_{1} / \mathrm{VC}$ with a more than $20 \%$ reduction in FVC.

\section{LABORATORY INVESTIGATIONS}

Plasma samples from all subjects were tested for the presence of Micropolyspora faeni antigen (Outcherlony technique, Mercia diagnosis, FSK3, Imunogenetics, Anvers, Belgium) as screening for farmers' lung. A positive result was taken as the presence of at least one precipitation arc.

\section{STATISTICAL ANALYSIS}

Prevalence indicates the number of subjects in the population under study who had a symptom or lung function abnormality. In a cross sectional study, prevalence is expressed as a percentage of the whole population investigated. Analysis of variance (ANOVA Statworks software) was used to compare the means of the parametric values, and the $\chi^{2}$ test was used to assess associations between discrete variables. Odds ratios (ORs) were used to indicate the degree of association between two dichotomous variables in stratified analysis. The ORs and confidence intervals ( $95 \% \mathrm{CIs})$ were calculated with the MantelHaenszel method. ${ }^{24}$ The factors influencing $\mathrm{FEF}_{25-75}$ and $\mathrm{FEV}_{1} / \mathrm{VC}$ were analysed by linear regression (Statworks software). The variables included were those that significantly correlated with the airway disease $(\mathbf{P}<0.05)$.

\section{Results}

CHARACTERISTICS OF THE POPULATION

From 1 November 1992 to 31 July 1993, 1473 subjects were sent written notifications (1270 for the free five yearly examination, and 203 employees for the obligatory annual medical examination). From the first group 952, and from the second 170 , went to these preventive medical tests. The final sample comprised 1122 subjects (718 men and 404 women), $76 \cdot 2 \%$ of the initial sample. They all agreed to participate and filled in the questionnaire. There were no differences in sex and age between initial and final samples. The mean (SD) age was 48.4 (12.9) years, and 619 people $(55 \cdot 2 \%)$ were over 50 years old. Average weight was $72(13 \cdot 1) \mathrm{kg}$. There were 203 smokers $(18 \cdot 1 \%), 152(13.5 \%)$ exsmokers, and $774(66 \%)$ non-smokers, and smoking habits were unknown in $27(2 \cdot 4 \%)$ cases. Body mass index (BMI) was 26.0 (4.5) in the men, and $26 \cdot 1(4 \cdot 3)$ in the women.

The farms were $<20$ hectares (ha) in 196 (15\%) cases, $21-49$ ha in $357(31.8 \%)$ cases, $50-69$ ha in $186(16.6 \%)$ cases, $>70$ ha in $294(26 \cdot 2 \%)$ cases, and unknown in 89 $(7 \cdot 9 \%)$ cases. The farming activities were classified as follows (multiple answers allowed): fruit farming $31 / 1122(2 \cdot 7 \%)$, horticulture $35(3 \cdot 1 \%)$, sheep and cattle breeding $969(86.4 \%)$, and mixed farming 472 $(42 \cdot 1 \%)$. The distribution of risk activities was (multiple answers allowed): grain milling $397 / 1122(35.4 \%)$, silage making 426 (38\%), grain silo work $59(5 \cdot 2 \%)$, hay storage 934 (83.2\%), fertilising $475(42 \cdot 3 \%)$, and exposure to pesticides $345(31 \cdot 7 \%)$. For 1043 people $(93 \%)$ who answered the questionnaire, 
exposure was divided into the following categories: exposure $<3$ months a year (class 1 , $\mathrm{n}=73$, $(6.5 \%))$, intermittent exposure $<3$ months a year (class $2, \mathrm{n}=30(2 \cdot 7 \%)$ ), exposure $<7$ hours a week (class $3, \mathrm{n}=241$ $(21.5 \%)$ ), exposure $>7$ hours a week (class 4 , $\mathrm{n}=699(62 \cdot 3 \%))$.

There were sex differences for certain classes of activity (table 1 ).

Table 1 Characteristics and occupational activities of both men and women $(n=1122)$

\begin{tabular}{lcc}
\hline & Women $(n=404)$ & Men $(n=718)$ \\
\hline Age & $52 \cdot 7(10 \cdot 3)$ & $46 \cdot 0(13 \cdot 7)$ \\
>50 y (\%) & $0 \cdot 667$ & $0 \cdot 458$ \\
Body mass index & $26 \cdot 18(4 \cdot 7)$ & $26 \cdot 0(4 \cdot 6)$ \\
& & \\
Non-smokers & $0 \cdot 896$ & $0 \cdot 5265$ \\
Ex-smokers & $0 \cdot 0173$ & $0 \cdot 2507$ \\
$\quad$ (mean (SD) pack-y) & $10 \cdot 5(6 \cdot 7)$ & $14 \cdot 6(13 \cdot 1)$ \\
Current smokers & $0 \cdot 057$ & $0 \cdot 202$ \\
$\quad$ (mean (SD) pack-y) & $13(13 \cdot 3)$ & $14 \cdot 3(12 \cdot 3)$ \\
Fruit farmers & $0 \cdot 0025$ & $0 \cdot 042$ \\
Horticulture & $0 \cdot 0025$ & $0 \cdot 047$ \\
Cattle breeding & $0 \cdot 928$ & $0 \cdot 827$ \\
Mixed farming & $0 \cdot 418$ & $0 \cdot 422$ \\
Grain milling & $0 \cdot 245$ & $0 \cdot 415$ \\
Silage making & $0 \cdot 269$ & $0 \cdot 441$ \\
Silo work & $0 \cdot 025$ & $0 \cdot 0682$ \\
Gathered hay & $0 \cdot 8812$ & $0 \cdot 805$ \\
Fertilisers & $0 \cdot 0546$ & $0 \cdot 631$ \\
Pesticides use & $0 \cdot 0371$ & $0 \cdot 4596$ \\
& & \\
Size of farms & & \\
<20 ha & $0 \cdot 255$ & $0 \cdot 1295$ \\
21-49 ha & $0 \cdot 404$ & $0 \cdot 274$ \\
$50-69$ ha & $0 \cdot 166$ & $0 \cdot 1657$ \\
$>70$ ha & $0 \cdot 166$ & $0 \cdot 316$ \\
Exposure intensity & & \\
1 & $0 \cdot 0545$ & $0 \cdot 071$ \\
2 & $0 \cdot 0198$ & $0 \cdot 031$ \\
3 & $0 \cdot 255$ & $0 \cdot 192$ \\
4 & $0 \cdot 621$ & \\
\hline
\end{tabular}

Table 2 Lung function tests between men and women

\begin{tabular}{lll}
\hline Predicted values (\%) & $\begin{array}{l}\text { Women }(n=355) \\
\text { mean }(S D)\end{array}$ & $\begin{array}{l}\text { Men }(n=672) \\
\text { mean }(S D)\end{array}$ \\
\hline FEV $_{1}$ & $106(15 \cdot 9)$ & $103 \cdot 2(23 \cdot 3)$ \\
FEV $_{1} /$ VC & $101 \cdot 6(7 \cdot 2)$ & $100 \cdot 6(9 \cdot 38)$ \\
FEV $_{25-75}$ & $79 \cdot 1(22 \cdot 3)$ & $90 \cdot 3(28 \cdot 6)$ \\
FEV $_{50}$ & $85 \cdot 3(24 \cdot 8)$ & $96 \cdot 8(32 \cdot 6)$ \\
FEV $_{25}$ & $69 \cdot 4(27)$ & $85 \cdot 4(37 \cdot 5)$ \\
\hline
\end{tabular}

RESPIRATORY SYMPTOMS AND LUNG FUNCTION TESTS

The prevalence of the various respiratory symptoms in the whole population was: chronic cough ( $>3$ months) $95(8.47 \%)$, chronic expectoration $86(7 \cdot 66 \%)$, moderate shortness of breath $234(20 \cdot 85 \%)$, notable shortness of breath $67(5.4 \%)$, cough or expectoration 146 (13\%), chronic bronchitis as defined from the questionnaire $86(7 \cdot 66 \%)$, history of cardiac or non-obstructive respiratory disease $244(21 \cdot 75 \%)$. All farmers had been raised on a farm and had worked in farming since their youth. The duration of employment in farming was roughly the same as chronological age minus 15 years. Table 2 shows the lung function results for men and women; the curves were interpretable in 1062 (95\%) subjects. The prevalence of distal airway obstruction was: $117(11.4 \%)$, overall airflow obstruction $33(3 \cdot 2 \%)$. Tables 3 and 4 summarise the respiratory symptoms and lung obstruction by smoking behaviour and nature of farm activity.

\section{LABORATORY TESTS}

The 14 subjects with positive serology $(1 \cdot 25 \%)$ were excluded from the OR and linear regression analyses as it was thought that lung function might have been affected by hypersensitivity pneumonia. The final sample thus comprised 1108 (75.5\%) people.

\section{DATA ANALYSIS}

Respiratory symptoms and airway obstruction (discrete variables) were analysed by $O R$ after stratification by confounding factors. We thus analysed the relative risk (measured by OR) between symptoms, airway disease, and some variables (age, size of farm, and exposure) after stratification by smoking habits. The following variables were studied: respiratory symptoms (cough, expectoration, chronic bronchitis, moderate dyspnoea), overall airflow obstruction, and distal airway obstruction (dichotomous variables).

In smokers, no differences were found in ORs between exsmokers and current smokers

Table 3 Respiratory symptoms and lung function in the whole sample by rural activity (n (\%))

\begin{tabular}{lllllrl}
\hline & Cough & Expectoration & Chronic bronchitis & History & Distal obstruction & Overall obstruction \\
\hline Cattle breeding $(\mathrm{n}=974)$ & $89(9 \cdot 1)$ & $80(8 \cdot 2)$ & $80(8 \cdot 2)$ & $214(22)$ & $99(10 \cdot 9)$ & $27(3)$ \\
Gathering hay $(\mathrm{n}=940)$ & $89(9 \cdot 36)$ & $75(8)$ & $74(7 \cdot 87)$ & $213(22 \cdot 7)$ & $101(11 \cdot 7)$ & $27(3 \cdot 1)$ \\
Mixed farming $(\mathrm{n}=476)$ & $39(8 \cdot 1)$ & $36(7 \cdot 56)$ & $35(7 \cdot 35)$ & $108(24 \cdot 7)$ & $56(12 \cdot 8)$ & $17(3 \cdot 9)$ \\
Grain milling $(\mathrm{n}=398)$ & $40(10 \cdot 05)$ & $40(10 \cdot 05)$ & $36(9 \cdot 05)$ & $93(23 \cdot 4)$ & $43(11 \cdot 7)$ & $11(3)$ \\
Fertilising ( $=477)$ & $45(9 \cdot 4)$ & $44(9 \cdot 2)$ & $43(9)$ & $45(24 \cdot 1)$ & $44(9 \cdot 8)$ & $13(2 \cdot 9)$ \\
Silage making ( $\mathrm{n}=427)$ & $32(7 \cdot 5)$ & $37(8 \cdot 6)$ & $35(8 \cdot 2)$ & $90(21 \cdot 1)$ & $41(10 \cdot 3)$ & $13(3 \cdot 3)$ \\
Pesticide use ( $=347)$ & $30(8 \cdot 65)$ & $30(8 \cdot 65)$ & $26(7 \cdot 5)$ & $79(22 \cdot 8)$ & $32(9 \cdot 8)$ & $8(2 \cdot 45)$ \\
Silo work $(\mathrm{n}=60)$ & $6(10)$ & $3(5)$ & $2(3 \cdot 3)$ & $13(21 \cdot 7)$ & $5(8 \cdot 6)$ & $1(1 \cdot 72)$ \\
\hline
\end{tabular}

${ }^{\star}$ History of cardiac or non-obstructive respiratory diseases.

Table 4 Respiratory symptoms and lung function by smoking ( $(\%)$ )

\begin{tabular}{lllllll}
\hline & Cough & Expectoration & Chronic bronchitis & History & Distal obstruction & Overall obstruction \\
\hline Non-smokers $(\mathrm{n}=740)$ & $58(7 \cdot 83)$ & $53(7 \cdot 1)$ & $53(7 \cdot 1)$ & $157(21 \cdot 22)$ & $72(9 \cdot 7)$ & $14(1 \cdot 9)$ \\
Ex-smokers $(\mathrm{n}=152)$ & $11(7 \cdot 24)$ & $13(8 \cdot 55)$ & $11(7 \cdot 23)$ & $45(29 \cdot 6)$ & $16(11 \cdot 1)$ & $2(1 \cdot 4)$ \\
Smokers $(\mathrm{n}=203)$ & $23(11 \cdot 3)$ & $21(10 \cdot 3)$ & $21(10 \cdot 3)$ & $36(17 \cdot 7)$ & $25(13 \cdot 9)$ & $16(7 \cdot 9)$ \\
\hline
\end{tabular}

${ }^{\star}$ History of cardiac or non-obstructive respiratory diseases. 
Table 5 Relative risk of symptoms and lung function by age and farm size in non-smokers with no history of cardiac or non-obstructive respiratory diseases

\begin{tabular}{|c|c|c|}
\hline & Age & Size of farm \\
\hline & $\begin{array}{l}\geqslant 50 y v<50 y \\
\text { OR }(95 \% C I)\end{array}$ & $\begin{array}{l}<50 \text { ha } v \geqslant 50 \text { ha } \\
\text { OR }(95 \% \text { CI })\end{array}$ \\
\hline $\begin{array}{l}\text { Cough } \\
\text { Expectoration } \\
\text { Chronic bronchitis } \\
\text { Dyspnoea } \\
\text { Distal obstruction } \\
\text { Overall obstruction }\end{array}$ & $\begin{array}{l}1.32(0.9-1.93) \\
1.12(0.95-1.19) \\
1.33(1.12-1.98) \\
2.03^{\star \star}(1.23-3.39) \\
2.30^{\star}(1.09-4.96) \\
0.71(0.5-1.01)\end{array}$ & $\begin{array}{l}0.97(0.96-1.02) \\
1.29(1.1-1.83) \\
1.29(1.08-1.79) \\
1.51^{\star}(0.36-6.42) \\
2.21^{\star}(1.06-4.66) \\
1.84(0.64-5.28)\end{array}$ \\
\hline
\end{tabular}

of their symptoms and lung function abnormalities for age, size of farm, or exposure. In non-smokers, values of $O R$ showed significant differences related to age for all symptoms and distal airway obstruction but not for overall airflow obstruction. For these subjects, there was a higher risk of shortness of breath and distal airway obstruction for people who lived on the smaller farms. No differences were found for exposure. In non-smokers with no history of cardiac or respiratory diseases, the ORs were only significant for dyspnea and distal airway obstruction for age and size of farm (table 5). We analysed the OR for size of farm after age adjustment. There were no significant differences for the symptoms and overall airflow obstruction, but the risk was still present for distal airway obstruction $(\mathrm{OR}=2.66(1.39-5.16), \mathrm{P}<0.001)$

\section{Analysis of quantitative airway obstruction by} correlation coefficient and linear regression

Linear regression was used to assess the factors that influenced the values of $\mathrm{FEV}_{1} / \mathrm{VC}$ (overall airflow obstruction) and $\mathrm{FEF}_{25-75}$ (distal airway obstruction). In the whole sample, smokers and non-smokers (table 6) the results are given by sex and history of cardiac and respiratory diseases. For $\mathrm{FEV}_{1} / \mathrm{VC}$, in men without a history of cardiac and respiratory disease, pack-years was the only significant variable, exposure and pack-years were significant in those with a history of cardiac and respiratory disease. In women without a history of cardiac and respiratory disease body mass index was significant, and age was significant in those with a history.
For $\mathrm{FEF}_{25-75}$ we found that in men with and without a history of cardiac or respiratory disease size of farms and pack-years were significant. Age and size of farms were the significant variables of the model in women without cardiac or respiratory disease, but age was the only significant variable in those with a history.

In the non-smokers with interpretable curves ( $n=649$, table 7 ) it was not possible to separate men and women (the number of women with lung function abnormalities was too small). The size of farm was the only significant variable in the model for overall airflow obstruction, age, and size of farm for distal airway obstruction.

The link between some variables was assessed from correlation coefficients. There was no correlation between the size of farm and the category of exposure, but there was a negative and strong correlation between age and size of farm $(\beta-4 \cdot 05$, SEM 11.77, $r$ 0.36): the older farmers worked on the smaller farms.

\section{Discussion}

This study shows that the prevalence of distal airway obstruction is higher than overall airflow obstruction in agricultural workers after stratification by smoking habits and history of cardiac or respiratory disease. Older people, who work on smaller farms, have the higher risk of distal airway obstruction.

\section{FACTORS THAT MAY HAVE INFLUENCED OUR} RESULTS

(1) Selection bias-Our sample comprised farmers, farm workers, and their spouses, who were all engaged in agricultural activities. Among the employees, the rates were higher as the examinations were obligatory. Of the people notified $23.8 \%$ did not come to preventive examinations. It was not possible to obtain any information about respiratory symptoms from these subjects. This is the usual rate of attendance for free medical examinations of farmers' insurance companies. The characteristics of our subjects (age, sex, smoking habits) are similar to other studies. ${ }^{427}$

(2) Reporting bias-Chronic bronchitis was

Table 6 Linear regression analysis of percentage of predicted values of $F E V_{1} / V C$ and $F E F_{25-75}$ as dependent variables in the whole sample according to history (selected variables are those significantly correlated with the dependent variable)

\begin{tabular}{|c|c|c|c|}
\hline Smokers and non-smokers & $\begin{array}{l}\text { Linear regression equation } \\
\text { regression coefficient, constant (SEM of estimate) }\end{array}$ & P value & $\begin{array}{l}\text { Explained } \\
\text { variance (\%) }\end{array}$ \\
\hline $\begin{array}{l}\text { Women without history } \\
\quad(n=283)\end{array}$ & $\begin{array}{l}\left.\mathrm{FEV}_{1} / \mathrm{VC}=0.213 \text { (body mass index }\right)+96.1(7.025) \\
\mathrm{FEF}_{25}=-0.55(\text { age })+3.29(\text { size of farm })+100(21)\end{array}$ & $\begin{array}{l}\text { body mass index } 0.024 \\
\text { age } 0.001 \\
\text { size of farm } 0.012\end{array}$ & $\begin{array}{r}3 \\
11\end{array}$ \\
\hline $\begin{array}{l}\text { Women with history } \\
(\mathrm{n}=65)\end{array}$ & $\begin{array}{l}\mathrm{FEV}_{1} / \mathrm{NC}=-0.182(\text { age })+111 \cdot 1(7.68) \\
\mathrm{FEF}_{25}=-0.78(\mathrm{age})+115 \cdot 6(26 \cdot 9)\end{array}$ & $\begin{array}{l}\text { age } 0.004 \\
\text { age } 0.004\end{array}$ & $\stackrel{6}{12 \cdot 8}$ \\
\hline $\begin{array}{l}\text { Men without history } \\
\quad(\mathrm{n}=559)\end{array}$ & $\begin{array}{l}\mathrm{FEV}_{1} / \mathrm{VC}=-0.114 \text { (pack-y) }+101.54(9.06) \\
\mathrm{FEF}_{25.75}=3.89(\text { size of farm })-0.55(\text { pack-y) }+83.89(26.9)\end{array}$ & $\begin{array}{l}\text { pack-y } 0.002 \\
\text { size of farm } 0.001 \\
\text { pack-y } 0.0001\end{array}$ & $\begin{array}{l}3 \\
7 \cdot 5\end{array}$ \\
\hline $\begin{array}{l}\text { Men with history } \\
\quad(\mathrm{n}=155)\end{array}$ & $\begin{array}{l}\mathrm{FEV}_{1} / \mathrm{VC}=1.286 \text { (exposure intensity) }-0.167 \text { (pack-y) }+95.81(9.41) \\
\mathrm{FEF}_{25}=-0.57 \text { (age) }-0.41(\text { pack-y })+113.75(27 \cdot 2)\end{array}$ & $\begin{array}{l}\text { exposure intensity } 0.013 \\
\text { pack-y } 0.011 \\
\text { age } 0.002 \\
\text { pack-y } 0.037\end{array}$ & $\begin{array}{l}7 \\
9 \cdot 8\end{array}$ \\
\hline
\end{tabular}


Table 7 Linear regression analysis of percentage of predicted values of $F E V_{1} / V C$ and $F E F_{25-75}$ as dependent variables in non-smokers by history (selected variables are those significantly correlated with the dependent variable)

\begin{tabular}{|c|c|c|c|}
\hline $\begin{array}{l}\text { Non-smokers } \\
\text { (men and women) }\end{array}$ & $\begin{array}{l}\text { Linear regression equation } \\
\text { regression coefficient, constant, (SEM of estimate) }\end{array}$ & $P$ value & $\begin{array}{l}\text { Explained } \\
\text { variance (\%) }\end{array}$ \\
\hline $\begin{array}{l}\text { With or without history } \\
(\mathrm{n}=649)\end{array}$ & $\begin{array}{l}\mathrm{FEV}_{1} / \mathrm{VC}=0.575(\text { size of farm })+100.07(8.37) \\
\mathrm{FEF}_{25-75}=-0.45(\mathrm{age})+5.0(\text { size of farm })+95.96(25.06)\end{array}$ & $\begin{array}{l}\text { size of farm } 0.06 \\
\text { age } 0.0001 \\
\text { size of farm } 0.0001\end{array}$ & $\stackrel{5}{11 \cdot 2}$ \\
\hline $\begin{array}{l}\text { Without history } \\
(n=511)\end{array}$ & $\begin{array}{l}\mathrm{FEV}_{1} / \mathrm{VC}=0.77(\text { size of farm })+100(8.44) \\
\mathrm{FEF}_{25-75}=-0.40(\text { age })+5.44(\text { size of farm })+93.5(24.98)\end{array}$ & $\begin{array}{l}\text { size of farm } 0.027 \\
\text { age } 0.0001 \\
\text { size of farm } 0.0001\end{array}$ & $\begin{array}{l}10 \\
11 \cdot 1\end{array}$ \\
\hline
\end{tabular}

${ }^{\star}$ History of cardiac or non-obstructive respiratory diseases.

diagnosed on the basis of the reported respiratory symptoms. The questionnaire was given by a physician to reduce the recording errors. Subjects might have been reluctant to report smoking habits, in view of the recent legislation against smoking in France. As all studies use a questionnaire of this type, our results should be comparable with those of other workers.

(3) Measurement bias-Lung function measurements were carried out by trained operators in an attempt to reduce variability. Curves that were not reproducible or interpretable were excluded from the analysis.

(4) Definition of airway obstruction-It was based on $\mathrm{FEV}_{1} / \mathrm{VC}$ and $\mathrm{FEF}_{25-75}$ with criteria extracted from Quanjer. ${ }^{23}$ These two dependent variables were expressed as a percentage of predicted values, adjusted for sex, age, height. These variables must not seem to be explicative, except in the case of correlation with another factor. Reference values are widely used in the European Community, unlike the United States. ${ }^{21}$ The FEF $_{25-75}$ has a higher sensitivity than $\mathrm{FEV}_{1}$ for distal airway obstruction, ${ }^{2026}$ and a reduced $\mathrm{FEF}_{25-75}$ in a rural population has been reported by other workers. ${ }^{2811}$ Lung function is a more objective way of assessing the influence of occupational factors and it is not unexpected that distal airway obstruction would be detected before any onset of symptoms. Lung function of subjects with distal airway obstruction and no symptoms could profitably be compared with those of the symptomatic patients in a longitudinal study.

Rate of chronic bronchitis in agricultural areas A recent epidemiological study, conducted by the National Center for Health Statistics, found a low prevalence of chronic obstructive pulmonary disease (COPD) in the general population of $5 \cdot 7 \%(6 \cdot 4 \%$ in males, $5 \cdot 2 \%$ in females). ${ }^{25}$ Brackbill and coworkers studied

Table 8 Prevalence of chronic bronchitis and smoking in some epidemiological studies

\begin{tabular}{|c|c|c|c|c|}
\hline & Population & $n$ & Smokers (\%) & Chronic bronchitis (\%) \\
\hline $\begin{array}{l}\text { Do Pico et } a l^{8} \\
\text { Dosman } e t a^{2} \\
\text { Saia et al } \\
\text { Milosevic et } a l^{5} \\
\text { Iversen and Pedersen }{ }^{13} \\
\text { Pariente et } a l^{26} \\
\text { Dalphin } e t a l^{6} \\
\text { Pham et al }{ }^{15} \\
\text { Gamsky et al }{ }^{14} \\
\text { Terho et al }{ }^{16} \\
\text { Dalphin } e t a l^{27}\end{array}$ & $\begin{array}{l}\text { Cereal workers } \\
\text { Cereal workers } \\
\text { Farmers } \\
\text { Farmers } \\
\text { Pig farmers } \\
\text { Rural workers } \\
\text { Farmers } \\
\text { Farmers } \\
\text { Farm workers } \\
\text { Farmers } \\
\text { Farmers }\end{array}$ & $\begin{array}{r}300 \\
90 \\
293 \\
414 \\
124 \\
1904 \\
250 \\
755 \\
759 \\
9853 \\
5703\end{array}$ & $\begin{array}{l}49 \\
0 \\
57 \\
63 \\
20 \\
60 \\
29 \\
21 \\
29 \\
35 \\
16 \cdot 5\end{array}$ & $\begin{array}{l}37 \\
23 \\
9 \cdot 6 \\
21 \\
24 \\
17 \cdot 5 \\
12 \\
16 \cdot 5 \\
5 \cdot 1 \\
8 \\
9 \cdot 3\end{array}$ \\
\hline
\end{tabular}

2681 farmers in the United States for five years; they found an age adjusted prevalence for chronic respiratory disease of $6 \cdot 7 \% .^{28}$ Results are higher in agricultural studies (table 8). The rates differ considerably depending on smoking habits and occupational activities..$^{4615}$ All studies except two $0^{912}$ found an increased incidence of respiratory symptoms and chronic bronchitis among agricultural workers. Some of them ${ }^{2811}$ found impaired lung function (lower $\mathrm{FEV}_{1}$, VC, $\mathrm{FEF}_{25-75}$ ), whereas others only found a reduction in $\mathrm{FEV}_{1}$ and VC, but not $\mathrm{FEV}_{1} / \mathrm{VC}$ and $\mathrm{FEF}_{25-75 .}{ }^{310}$ The high proportion of smokers might have influenced the results of some studies. $^{526}$ In a cross sectional study of an agricultural population in Finland, Terho and coworkers found a similar incidence of chronic bronchitis to that found in our study ( $8 \%$ in the whole population, $7.6 \%$ in cattle farmers). ${ }^{16}$ In that study, smokers made up $35.4 \%$ of the population $(58.6 \%$ of the men, $10 \cdot 2 \%$ of the women). ${ }^{16}$ Dalphin et al, in another French agricultural area, found similar results: a prevalence of chronic bronchitis of $9.3 \%$ with a smoker rate of $16.5 \%(18 \cdot 1 \%$ in our study)..$^{27}$

\section{Explanatory analysis}

Pack-years emerged as the main variable to influence airway obstruction in the smokers. As in all studies of chronic bronchitis, smoking is the main confounding factor. There was a comparable prevalence of chronic bronchitis in the exsmokers and current smokers as they had the same cumulative exposure (pack-years). We also wished to eliminate another confounding factor-namely, history of cardiac and non-obstructive respiratory diseases - that could alter both the perception of symptoms by the patients and the lung function tests. This factor has seldom been taken into account in other studies. In these selected subjects, distal airway obstruction was still present, with age and size of farm being the two main explanatory variables.

The exposure definition we used was invalid as more than two thirds of the population fell into class 4 . It was not possible to define another group after the first results as the questionnaire only provided information on weekly activities. This is another limitation of the study, but it was not the main objective. In some selected occupational activities such as grain milling, it is possible to assess exposure from variables such as dust concentration, ${ }^{310}$ but in agriculture several agents may 
be responsible for chronic injury to airways (cattle feeding, grain milling, hay storage, inhalation of pesticides, as well as climatic conditions). Although exposure can be quantified, it does not provide a picture of total exposure to risks. Some studies have attempted to assess exposure in terms of time spent in certain activities-for example, threshing or cattle feeding - although they failed to detect any correlation between chronic bronchitis and the duration of exposure. ${ }^{4614}$

Despite the fact that observed values were related to the predictive values, age appeared in the analysis. It is possible that age represents an indirect measurement of the duration of exposure. Some studies have the same results: age may be a reflection of cumulative exposure..$^{111} \mathrm{We}$ found a relative risk for distal obstruction of 3.02 for the smaller farms ( $<50$ hectares) $v$ the larger farms, which is in line with the findings of Saia et al. ${ }^{4}$ This risk was still present, after stratification by age $(O R=2 \cdot 66)$. It may be that the smaller farms employ less mechanised equipment, thereby increasing exposure to certain risks. Analysis of characteristics of agricultural activities obtained from a more detailed questionnaire could perhaps provide an answer to this question.

In summary, this study shows that the prevalence of distal airway obstruction is higher than the prevalence of chronic bronchitis in an agricultural population, after stratification by smoking habits and history of cardiac and other respiratory diseases. Age and size of farms, which are negatively correlated, emerge as the two main explanatory variables. These results indicate that farming populations may have an early propensity to distal airway obstruction. The next steps should be to define agricultural exposure by creating a more detailed questionnaire, and to provide more evidence for the hypothesis that size of farm is a risk factor for respiratory diseases.

We thank Professor F Boutros-Toni for his technical assistance in statistical methods. This work was supported by a grant from Mutualite Sociale Agricole and Groupam Insurance, Limoges, France.

1 Schenker M, Ferguson T, Gamsky T. Respiratory risks associated with agriculture. $₹$ Occup Med 1991;6:415-28. Dosman JA, Cotton DJ, Graham BL, Robert Li KA Barnett GD. Chronic bronchitis and decreased forced expiratory flow rates in lifetime non-smoking grain workexpiratory flow rates in lifetime non-sm

3 Chan-Yeung M, Schulzer M, MacLean L, Dorken E Grzybowski S. Epidemiologic health survey of grain elevator workers in British Columbia. Am Rev Respir Dis 1980;121:329-38.
4 Saia B, Mastrangelo G, Marcer G, Reggio O. Prevalence and risk factors of chronic respiratory disease in a farming population. Med Lav 1984;75:101-9.

5 Milosevic M. The prevalence of chronic bronchitis in agricultural workers of Slavonia. Am F Ind Med 1986;10: 319-22.

6 Dalphin JC, Bildstein F, Pernet D, Dubiez F, Depierre A Prevalence of chronic bronchitis and respiratory function in a group of dairy farmers in the French Doubs province. Chest 1989;95:1244-7.

7 Rylander R. Lung diseases caused by organic dusts. $\mathrm{Am} f$ Ind Med 1986;10:221-7.

8 Do Pico GA, Reddan W, Tsiatis A, Peters ME, Rankin J. Epidemiologic study of clinical and physiologic parameEpidemiologic study of clinical and physiologic parameters in grain handlers of norther
Respir Dis 1984;130:759-65.

9 Manfreda J, Cheang M, Warren CPW. Chronic respiratory disorders related to farming and exposure to grain dust in a rural adult community. Am $\mathcal{F}$ Ind $\mathrm{Med}$ 1989;15:7-19.

10 Chan-Yeung M, Dimich-Ward H, Enarson DA, Kennedy SM. Five cross sectional studies of grain elevator workers. Am ₹ Epidemiol 1992;136:1269-79.

11 Dosman JA, Graham BL, Hall D, Loon PV, Bahsin P, Froh F. Respiratory symptoms and pulmonary function in farmers. $¥$ Occup Med 1987;29:48-3.

12 Heller RY, Hayward DM, Farebrother MTB. Lung function in farmers in England and Wales. Thorax 1986; tion in farme

13 Iversen M, Pedersen B. Relation between respiratory symptoms, type of farming, and lung function disorders in farmers. Thora 1990;45:919-23.

14 Gamsky TE, Schenker MB, McCurdy SA, Samuels SJ Smoking, respiratory symptoms, and pulmonary function among a population of hispanic farmworkers. Chest 1992;101:1361-8.

15 Pham QT, Teculescu D, Chau N, Bouchy O, Constantino E, Moneret-Vautrin D. Etude respiratoire et allergologique dans le milieu agricole du département de la Meuse. Arch Mal Prof 1991;52:467-75.

16 Terho EO, Vohlonen I, Husman K. Prevalence and incidence of chronic bronchitis and farmer's lung with respect to socioeconomic factors. Eur $¥$ Respir Dis 1987; 71:S29-36.

17 Malmberg P, Rask-Andersen A. Natural and adaptative immune reactions to inhaled microorganisms in the lungs of farmers. Scand $\mathcal{F}$ Work Environ Health 1988 1:S68-71.

18 Rask-Andersen A, Malmberg P, Lundholm M. Endotoxin levels in farming: absence of symptoms despite high exposure levels. Br f Ind Med 1989;46:412-6.

19 Revsbech $\mathrm{P}$, Andersen G. Diurnal variation in peak expiratory flow rate among grain elevator workers. $\mathrm{Br} \mathcal{f}$ Ind Med 1989;46:566-9.

20 Prefault Ch, Tcheriatchoukine J, Guerrero AJ, Moutou H, Chardon G. Débit maximum expiratoire $25-75 \%$ dans une population de non fumeurs. Bull Eur Physiopath Resp 1980;16:25-40.

21 American Thoracic Society. Lung function testing: selection of reference values and interpretative strategies. $\mathrm{Am}$ tion of reference values and interp
Rev Respir Dis 1991;144:1202-18.

22 Organisation Mondiale de la Santé. Questionnaire sur les symptômes respiratoires in OMS ed: le dépistage précoce des maladies professionnelles, 1st ed. Genève: Organisation Mondiale de la Santé, 1989: 278-83.

23 Quanjer P. Standardized lung function testing. Bull Eu Physiopath Respir 1985;19:S45-51.

24 Mantel N, Haenszel W. Statistical aspects of the analysis of data from retrospective studies of diseases. 7 Nat Cancer Inst 1959;22:719-48.

25 McWhorter, Polis M, Kalow R. Occurrence, predictors, and consequences of adult asthma in the NHANES-I and follow-up survey. Am Rev Respir Dis 1989;139: and follo 4 .

26 Pariente R, Coulaud C, Martin JP, Berthet C, Baldayrou $P$, Touaty E. Enquête sur les bronchopneumopathies chroniques en milieu agricole. Rev Fr Mal Respir 1979, 7:633-8.

27 Dalphin JC, Debieuvre D, Pernet D, Maheu MF, Polio $\mathrm{JC}$, Toson B, et al. Prevalence and risk factors for chronic bronchitis and farmer's lung in French dairy farmers. Br F Ind Med 1993;50:941-4.

28 Brackbill RM, Cameron LL, Behrens V. Prevalence of chronic diseases and impairments among US farmers, 1986-1990. Am f Epidemiol 1994;139:1055-65.

\section{Rejected manuscripts}

From February 1994, authors whose submitted articles are rejected will be advised of the decision and one copy of the article, together with any reviewers' comments, will be returned to them. The fournal will destroy remaining copies of the article but correspondence and reviewers' comments will be kept. 